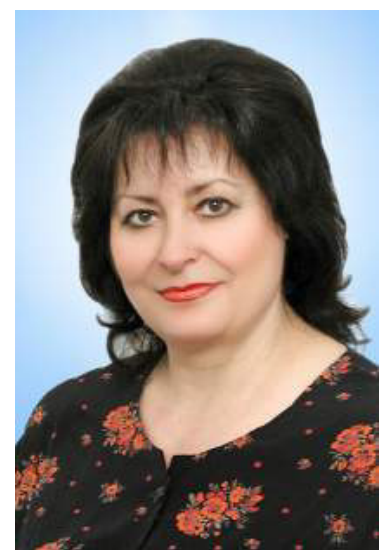

\author{
Ореста Ткачук, \\ кандидат педагогічних наук, доцент, \\ ДВНЗ «Прикарпатський національний \\ університет імені Василя Стефаника» \\ (м. Івано-Франківськ)
}

\author{
Oresta Tkachuk, \\ (Ivano-Frankivsk) \\ oresta.tkachuk@pu.if.ua \\ ID orcid.org/0000-0003-3667-7956
}

Candidate of Pedagogical Sciences, Associate Professor, Vasyl Stefanyk Precarpathian National University

\title{
РОБОТА ЗІ СЛОВНИКОМ ЯК ЗАСІБ РОЗВИТКУ МОВЛЕННЯ МОЛОДШИХ ШКОЛЯРІВ В УМОВАХ ГІРСЬКОЇ ШКОЛИ
}

\section{VOCABULARY WORK AS A MEANS FOR DEVELOPING SPEAKING OF SCHOOL SCHOOLS IN CONDITIONS OF MOUNTAIN SCHOOL}

\begin{abstract}
У статті розглянуто ідею створення та використання «ручного» комплексного універсального словника, який в одній словниковій статті уміщає відомості про правопис, значення, походження, синонімічні, антонімічні особливості та вживання слів, уміщених у вправах і текстах підручників та книг, призначених для читання у початковій школі, проілюстровано словникові статті такого словника та наголошено на його необхідності для педагогічного процесу гірської школи. Наведено результати анкетування педагогічних працівників гірських шкіл щодо роботи зі словником у школі та приклади використання комплексного універсального словника у педагогічній практиці.

Ключові слова: універсальний комплексний словник, гірська школа, словникова стаття, реєстрове слово.

The article considers the idea of creating and using a "manual» comprehensive universal dictionary, which in one dictionary article contains information on spelling, meaning, origin, synonym, antonymic peculiarities and the use of words contained in the exercises and texts of textbooks and books intended for reading in the school. The article gives examples of vocabulary articles of this dictionary. The article emphasizes that this vocabulary is necessity for the pedagogical process of the mountain school. The results of the questionnaire of pedagogical workers of mountain schools about working with a dictionary at school and examples of the use of complex universal vocabulary in pedagogical practice are given.

Key words: universal complex dictionary, mountains school, vocabulary article, registered word.

В статье рассмотрена идея создания и использования «ручного» комплексного универсального словаря, который в одной словарной статье вмещает сведения о правописании, значении, происхождении, синонимичные, антонимичные особенности и употребление слов, помещенных в упражнениях и текстах учебников и книг, предназначенных для чтения в начальной школе; проиллюстрировано словарные статьи такого словаря и отмечена его необходимость для педагогического процесса горной школы. Приведены результаты анкетирования педагогов горных школ по работе со словарем в школе и примеры использования комплексного универсального словаря в педагогической практике.

Ключевые слова: универсальный комплексный словарь, горная школа, словарная статья, реестровое слово.
\end{abstract}

Постановка проблеми в загальному вигляді та її зв'язок з важливими науковими та практичними завданнями. Галопуючий розвиток сучасного суспільства вимагає нових підходів до організації освіти підростаючого покоління, яке уже завтра стане творцем нового життя. Це спонукає до пошуків методів і прийомів роботи у практиці вчителя, які б дозволили забезпечити більш оптимальний процес здобуття освіти дітьми різних вікових категорій - від найменших школярів до випускників загальноосвітньої школи. Важливим компонентом становлення особистості є її здатність володіти мовленням - у всіх його проявах. Процес розвитку мовлення розпочинається ще на етапі первинного засвоєння мови у ранньому віці дитини і відбувається упродовж усього освітнього періоду дитини. Потрапляючи до школи, учень опановує нові слова, слухаючи учителя, читаючи навчальні книги, використовуючи наочні посібники, різні навчальні матеріали.

Молодші школярі гірських шкіл перебувають в особливих умовах. Вони мешкають часом у віддалених від школи районах, а тому їм доводиться долати великі відстані, щоб потрапити на навчання. Через суворі погодні умови вони змушені залишатись подекуди і на кілька днів дома і самостійно опановувати навчальний матеріал. Крім того, домашнє господарство, яке $є$ невід'ємним елементом буденності в горах, є вагомою причиною того, 
щоб постійно тратити час на допомогу батькам у проведенні сільськогосподарських робіт - як сезонних, так і щоденних. Все це диктує потребу організації навчання молодшого школяра в умовах гірської школи таким чином, щоб націлити дитину на самостійне навчання та максимально спростити маленькому школяреві здобуття знань, передбачених навчальною програмою.

Аналіз останніх досліджень і публікацій, у яких започатковано розв'язання проблеми. Проблеми розвитку мовлення дітей, які навчаються у початковій школі, знайшли відображення у працях цілої плеяди вчених - як вітчизняних, так зарубіжних: починаючи від Я.-А. Коменського, І.Песталоцці, Ф.Буслаєва, О.Потебні, М.Костомарова, К.Ушинського, М.Драгоманова, Б.Грінченка та ін. Сучасні дослідники Безпояско О.К., Городенська К.Г., Грищенко А.П., Єрмоленко С., Кононенко В., Мацько Л.І., Плющ М.Я.,. Тоцька Н.І., Шевчук С.В. Шкуратяна Н.Г. вважають мовну освіту фундаментом формування свідомої людини - громадянина України. Методичні аспекти питання розвитку мовлення молодшого школяра на уроках української мови розглядались у дослідженнях сучасних учених М. Вашуленка, О. Савченко, Т. Потоцької, С.Дорошенка, О.Хорошковської, Н.Воскресенської, А.Мовчун, М.Крикун, С.Дубовик. У працях методистів - як минулих років, так і сучасних - знаходимо цікаві думки про роботу з різноманітними словниками під час уроків української мови та літературного читання у початковій школі.

Формування мети статті. Метою статті стала потреба актуалізації та практичної реалізації ідеї про необхідність створення та використання спеціального універсального комплексного словника, призначеного як для самостійної роботи, так і під час уроку у ході навчальної діяльності молодшого школяра на уроках української мови та літературного читання в умовах гірської школи.

Виклад основного матеріалу дослідження з повним обґрунтуванням отриманих наукових результатів. Необхідність реалізації лінгвістичної лінії в процесі освіти молодшого школяра, задекларованої Державним стандартом, зумовлює потребу пошуків нових шляхів у розвитку мовлення учня та поглибленні його знань про слово як структурний елемент усієї системи сучасної української мови. Лінгвістична лінія Державного стандарту початкової освіти передбачає вироблення у молодших школярів умінь користуватись словниками, визначати синоніми, антоніми, пояснювати найуживаніші омоніми та фразеологізми. Для роботи у початковій школі Держстандарт конкретно називає тлумачний і фразеологічний словники. Учительська практика засвідчує, що вже у першому класі учні знайомляться зі словником орфографічним.

Сьогодні у практичному використанні перебуває уже певна база словників, призначених для початкової школи. Так, тільки один з інтернет-ресурсів наводить такі: А. А. Бондаренко, І. В. Гуркова «Говори правильно: орфоепічний словничок для учнів початкових класів»; В. В. Воліна «Фразеологічний словник»; П. А. Грушник «Орфографічний словничок»; Е. Н. Леонович «Орфографічний словник для початкової школи: Лексикографічний мінімум»; Е. Н. Леонович «Тлумачний словник»; М. Р. Львів «Словничок синонімів і антонімів для початкових класів»; Н. М. Неусипова «Тлумачний словничок» та ін.

Ще в середині XIX ст. І.І.Срезневський вперше висловив думку про необхідність так званого «ручного» словника, у якому учень міг би відшукати різноманітні відомості про слово [6]. По суті, такий словник становить поєднання різних типів словників, які вже існують як окремі самостійні. У ньому дитина могла б знайти відповіді на питання про значення, правопис, творення та походження слова, особливості його вживання. Якщо для одержання такої інформації учневі необхідно скористатися кількома словниками, то такий «ручний» комплексний словник зекономить затрати часу на пошуки необхідного типу словника та на пошуки відповідних словникових статей у ньому. Особливо це актуально для молодшого школяра гірської школи, у бібліотеці якої часом бракує відповідних словників, з яких можна було б почерпнути відомості різного плану, або ж вони далеко не найновішого видання.

Сучасні укладачі вже здійснили спроби реалізувати ідею створення такого комплексного довідкового джерела для учнів початкової школи. Так, у видавництві «Ранок» вийшов з друку «Універсальний комплексний словник-довідник молодшого школяра», укладачами якого є Н.О.Воскресенська та К.О.Воскресенська. Посібник поділений на розділи, що становлять окремі невеликі за обсягом словнички: тлумачний, орфографічний, орфоепічний, словник наголосів, словотвірний, словник синонімів і антонімів, словник омонімів, етимологічний, фразеологічний, народознавчий, словник іншомовних слів та словник імен, а також короткий довідник 3 української мови [1]. Однак дитині, яка ще не має вироблених навичок користування такою довідковою літературою, важко орієнтуватися у лабіринті розділів книги, адже щоб знайти необхідні відомості про слово, треба проглянути кілька груп слів, що може стати причиною банального знеохочення.

у підручниках з української мови та літературного читання традиційно вміщено слова, які потребують словникової роботи. Вони супроводжуються поясненнями та тлумаченнями. Їх кількість у підручниках з української мови, для прикладу в 3 і 4 класах коливається від 80 до 60 слів. Дані слова знаходять своє відображення у чинних підручниках: вулиця, голка, фартух, Київ, бджола, волосся, грім, друзі, зозуля, картопля, майже, пізніше та ін. Однак учні гірського регіону Українських Карпат, які на щодень послуговуються говірками, віддаленими від літературного варіанту української мови, незрозумілих для себе слів знайдуть набагато більше. Зрештою, серед слів, які трапляються тільки у текстах вправ, є багато таких, що не пов'язані з щоденним життям дітей, рідко вживаних або й застарілих. У підручниках з української мови та літературного читання для 1-4 класів ми натрапили на значний пласт слів, що належать до пасивної лексики, та значну кількість слів, котрі, 
на нашу думку, будуть не зовсім сприйнятими учнями початкових класів, оскільки їх значення у підручниках не наведені, а якщо наведені, то не зовсім точно: узвіз, трелі, дубняк, зодчий, верболози, прожогом, пуд, стерно, навпочіпки, сториця, тенета, рундук, фелюга, баркас, хуга, терем, томагавк та ін.

Використання словників різних типів у школі стимулює інтерес учнів до мови, допомагає краще засвоїти матеріал, суттєво скорочує час дитини на пошуки необхідного, дає змогу успішно користуватись словниковим багатством мови та виробити уміння послуговуватись словником. Однак на практиці учні гірських шкіл не мають можливості користуватись різнотипними словниками. Це засвідчують результати анкетування, проведеного нами серед учителів районів Івано-Франківської області. В анкетуванні взали участь 34 учителі початкової школи, з них 14 осіб - Ворохтянського району. У результаті анкетування ми встановили, що більшість учителів (28) мають стаж педагогічної роботи 23-25 років, а отже, їх педагогічний досвід є великим і заслуговує уваги.

На запитання про те, як часто анкетовані використовують словники у ході уроків з української мови та літературного читання, ми отримали відповіді, які розділились таким чином: систематично - 0\%; 5-6 разів за півроку - 85\%; 1-3 рази за рік - 12\%; не використувую - 1\%, не знаю - 2\%. На запитання «Які типи словників Ви використовуєте під час уроків української мови та літературного читання ?» ми отримали відповіді: тільки орфографічний словник 58\%; орфографічний та тлумачний словники - 14\%; орфографічний, тлумачний та перекладний словники - 22\%; орфографічний, тлумачний, перекладний, синонімічний, фразеологічний словники - 6\%.

Ми запропонували анкетованим учителям самостійно визначити причини несистематичного використання словників на уроках у початковій гірській школі та назвати труднощі роботи зі словником. Погрупувавши варіанти відповідей, ми виділили такі причини: відсутність потрібних словників у необхідній кількості у шкільній бібліотеці - 74\%; відсутність інтересу до роботи зі словником у школярів - 22\%; відсутність інтересу до роботи зі словником у вчителя - 4\%.

Далі ми здійснили спробу з'ясувати, чи існуючі словники для початкової школи задовільняють потреби словникової роботи на уроках української мови та літературного читання. Одержані відповіді розділились таким чином: так - 9\%; частково так - 3\%; ні - 83\%. Учителі визначили такі найважливіші причини: 1) реєстрові слова до словників дібрані невдало: відсутні слова, які трапляються в текстах для читання чи вправах і потребують пояснення, у той час, коли у словниках уміщені слова, які не є частотними у мові та не становлять нагальної необхідності у мовленні молодших школярів - 32\%; 2) через багатошаровість і розпорошеність інформації учням молодших класів важко орієнтуватись у словниках - 46\%; 3) словники часом незручні у користуванні через громіздкість та поліграфічну непривабливість - 10\%. Насамкінець ми запитали, чи вважають учителі доцільним створення і використання такого комбінованого універсального словника, який би поєднував у собі відомості $з$ кількох типів словників, з добором реєстрових слів, необхідних для учня початкової школи. Одержані відповіді: так - 88\%; ні - 8\%; не знаю - 4\%. Серед причин недоцільності створення такого словника анкетовані назвали: 1) тому, що це буде ще більше заплутувати дітей і не сприятиме скороченню затрат часу на підготовку завдань - 4\%; 2) можна обійтись існуючими словниками та інтернетними джерелами - 2\%; 3) такий словник створити неможливо - $2 \%$.

Як бачимо, вчителі гірських районів несистематично використвують словники під час уроків української мови та літературного читання. 3 усього розмаїття сучасних словників у школах використовуються переважно орфографіний та перекладний словники. Це пов'язано зі слабким бібліографічним забезпеченням шкільних бібліотек. Нерідко школа має всього 3-4 примірники словника, а для оптимальної роботи 3 ним на уроці потрібно їх стільки, скільки учнів у класі. Існуючі словники, призначені для дітей молодшого шкільного віку, часто недосконалі поліграфічно й змістово, відзначаються невиправданістю добору реєстрових слів та нечіткістю або занадто складним викладом-тлумаченням у словникових статях. Тому абсолютна більшість опитаних підтримала доцільність існування і практичного використання такого комплексного словника.

Це наштовхнуло нас на створення такого комплексного «підручного» чи «ручного» словника, який в одній словниковій статті містив би відомості з правопису слова, його походження, значення та вживання, а в разі необхідності - синоніми, антоніми та омонімічні значення. Робота велася в кількох напрямах. Ми проводили опитування учителів та учнів, аналізували шкільні навчальні книги, проводили експериментальні дослідження щодо апробації невеликих за обсягом словників. До експериментальної роботи були залучені студенти наукового гуртка «Лексикографічна робота в початковій школі» педагогічного факультету ДВНЗ «Прикарпатський національний університете імені Василя Стефаника», які брали активну участь у всіх етапах експериментальної роботи.

Студенти педагогічного факультету здійснили спроби створення варіантів комплексного словника під час проходження педагогічної практики у школах області. Результати експериментальної роботи та апробації використання таких словників знайшли відображення у низці дипломних та магістерських робіт та оприлюднені у ході студентських наукових конференцій і в публікаціях.

Створений нами словник поєднував у собі такі основні принципи: розміщення слів у алфавітному порядку; орієнтація на загальновживану частотну лексику, а також на ті, що трапляються у шкільних підручниках, текстах для читання, рекомендованих шкільною програмою для учнів початкової школи; наявність відомостей про правопис слова і узгодженість орфографічних відомостей з принципами орфографічного словника: граматичні форми слів подаються як скорочено, так і повністю - відповідно до потреби; узгодженість членування морфем 
у словнику з сучасним розумінням морфемної будови слова. Морфеми у словнику мають позначки, прийняті у початковій та середній школі; всі слова подаються з наголосами; повнозначні слова містять у словниковій статті тлумачення значень. При цьому використано основні засади побудови тлумачного словника: у тлумаченні стисло розкриваються значення слів. Однак для багатозначних слів подано тільки найуживаніші значення. Якщо слово має кілька значень, то вони нумеруються арабськими цифрами, під № 1 іде найуживаніше значення, а решту - у спадному порядку частотності уживання. У разі необхідності подаються синонімічні та антонімічні слова чи конструкції. Окремі значення слова ілюструються прикладами, які сприяють більш повному розумінню значення слова та його вживання. Етимологічна інформація до слів подається на основі етимологічного словника української мови у спрощеному вигляді. Вказується, з якої мови запозичене це слово, або ж джерела та шляхи його появи в українській мові. Іноді вказано відповідники даного слова в інших мовах.

Такий, для прикладу, вигляд має словникова стаття до реєстрового слова ДВА:

ДВА.ДВОХ, Д.в. ДВОМ, О.в.ДВОМА; ж.р. - ДВІ, ДВОХ.

Виникло ще тоді, коли всі люди, що жили на території Індії і Європи, говорили мовою, що мала спільні слова. Тому у всіх так званих індоєвропейських мовах звучання цього слова подібне і означає воно число два. Порівняйте: литовське ДИ, пруське ДВАЙ, латинське ДУО, словацьке ДВА, російське ДВА.

Ось приклад словникової статті до слова ЗЕЛЕНИЙ:

ЗЕЛЕНИЙ, -А, -Е, -І.

1.Один із семи кольорів райдуги, колір свіжої трави, листя.

2.Рослинний, що походить з рослин (зелені насадження, зелений борщ).

3.Недостиглий, недозрілий (про плоди і овочі) (зелені яблука).

4.Недосвідчений, тому що молодий, незрілий за віком.

Походить від давнього слов'янського слова ЗЕЛО - трава, зелень.

Висновки і перспективи подальших досліджень. Таким чином, основним напрямом розвитку - мовлення молодших школярів залишається робота над словом, яка повинна проводитись учителем систематично, цікаво й у тісній взаємодії з учнями. Серед усього розмаїття методів і прийомів цієї роботи ми розглянули так званий комплексний підручний, універсальний словник, який поєднує у собі одразу кілька типів словників. Його використання на уроках української мови та літературного читання у початковій школі повинно бути добре продуманим, методично обгрунтованим, доцільним педагогічно, проводитись тільки за умов творчого підходу вчителя. Такий словник особливо доцільним бачиться в школах, у яких учні часом упродовж певного часу змушені самостійно поратись з завданнями через неможливість потрапити на уроки; в школах, які не завжди мають належно укомплектовані бібліотеки. Це стосується у першу чергу учнів гірських шкіл. Перспективою подальшого дослідження вважаємо добір і укладання спеціального комплексного словника, орієнтованого на конкретні регіони України, до реєстру якого увійшли б необхідні для запам'ятання слова, а також маловживані або застарілі слова, які трапляються у вправах чи текстах, призначених для читання у початковій школі

1. Воскресенська Н.О., Воскресенська К.О. Універсальний комплексний словник-довідник молодшого школяра / Н.О.Воскресенська, К.О.Воскресенська // [Електронний ресурс] - http://www.ranok.com.ua/ru/info-universalqnijkompleksnij-slovnikdovidnik-molodshogo-shkolyara-4553.html

2. Крикун М. Роль слова в розвитку зв'язного мовлення молодших школярів // Початкова школа. - 2003. - №11. - С. 27-35.

3. Маркова К.І. Словникова робота на уроках української мови в початкових класах / К.І. Маркова // [Електронний ресурс] http://osvita.ua/school/lessons_summary/initial/6257/

4. Попова Л. Етимологічний аналіз слів як засіб формування орфографічної грамотності молодших школярів / Л. Попова // [Електронний ресурс] - http:// vuzlib.com.ua/articles/book/36642-Etimolog\%D1\%96chnijj_anal\%D1\%96z_sl\%D1\%96v/ 1.html

5. Прищепа К. С. Тематичний словник школяра / К. С. Прищепа, В. Г. Лук'яненко. - К. : Гала, 1997. - 336 с.

6. Срезневский И.И. Русское слово / И.И. Срезневский. - М.: Просвещение, 1986.

\section{Reference}

1. Voskresenska N.O., Voskresenska K.O. Universalnyj kompleksnyj slovnk-dovidnyk molodshogo shkolara /Voskresenska N.O., Voskresenska K.O.// [Elektronnyi resurs] - http://www.ranok.com.ua/ru/info-universalqnij-kompleksnij-slovnikdovidnikmolodshogo-shkolyara-4553.html

2. Krikun M. Rol slowa w rozwytku zwjaznoho movlenja vjkjlshyh shkolariv/ Krikun M.///Pochatkowa shkola. 2003. 11. S.27-35.

3. Markova K.I. Slovnykova robota na urokakh ukrainskoi movy v pochatkovykh klasakh / K.I. Markova // [Elektronnyi resurs] http://osvita.ua/school/lessons_summary/initial/6257/

4. Popova L. Etymolohichnyi analiz sliv yak zasib formuvannia orfohrafichnoi hramotnosti molodshykh shkoliariv / L. Popova // [Elektronnyi resurs] - http://vuzlib. com.ua/articles/book/36642 Etimolog\%D1\%96chnijj_anal\%D1\%96z_sl\%D1\%96v/ 1.html

5. Pryshchepa K. S. Tematychnyi slovnyk shkoliara / K. S. Pryshchepa, V. H. Lukianenko. - K. : Hala, 1997. - 336 s.

6. Sreznevskyj I.I. Russkoje slowo /I.I. Sreznevskyj/ - M.: Prosveshchenije,1986. 